\title{
Serbian Political Leadership: Archetype and Modernity*
}

Zarys treści: Analiza archetypu serbskiego przywództwa politycznego i porównanie go z modelem współczesnym, na bazie tradycji i oczekiwań serbskiego społeczeństwa wobec lidera.

Outline of content: The article analyzes the archetype of Serbian political leadership and compares it with the present-day model, on the basis of traditions and expectations of the Serbian society of their leader.

Słowa kluczowe: Serbia, Bałkany, społeczeństwo serbskie, serbska klasa polityczna, Miloš Obrenović, Nikola Pašić, Slobodan Milošević

Keywords: political leadership, Ottoman legacy, Balkans, Serbia, Serbian society, Miloš Obrenović, Nikola Pašić, Slobodan Milošević

The model of Serbian political leadership and factors that have shaped it have hitherto received relatively little scholarly attention and there has been no attempt to look at the problem from a broader historical perspective. This article addresses the question concerning the existence of some archetype of Serbian political leadership, its character and factors that have contributed to its development and whether in modern Serbian history the perception of leadership has changed. The main hypothesis to be tested is that the character of Serbian society and its psyche have been the principal factor shaping its specific model of political leadership. In Serbian society, the process of modernization progressed slowly and the values fundamental to the $19^{\text {th }}$-century society would remain relevant for a long time leaving no room

* Research presented in this article was financed by the grant of the National Science Center UMO-2011/03/B/HS3/01453. 
for revolutionary change. Leadership cannot be detached from the given society's specific character and consequently this article is concerned with the factors exerting particularly strong influence upon Serbia's political leaders. The leadership of Prince Miloš, Nikola Pašić, and Slobodan Milošević is analyzed from the perspective of their respective cultural and historical determinants to ascertain whether there existed any common factors between the diverse historic periods in which these leaders were active. Methodologically, the article is based on Aaron Wildavskyi's cultural theory of leadership. According to Wildavskyi, leadership is the function of the type of regime or political culture, therefore, "under fatalistic regime leadership is despotic - continuous and total; under equities regime is ipso facto inegalitarian", and therefore it had to be charismatic. ${ }^{1}$ Consequently, Miloš Obrenović's leadership, as a legacy of Ottoman times, was despotic but evolved into charismatic because his regime transformed from fatalistic to egalitarian. Charismatic leadership continued and was strengthened under the rule of Prime Minister Nikola Pašić and President Slobodan Milošević. President Miloševićs leadership referred to the legacy of Communist equality and equity and the charismatic rule of Josiph Bros Tito as the most profound historical experience of the Serbian people.

\section{Prince Miloš Obrenović}

The rule of Prince Miloš may be analyzed from various perspectives but the one relevant here concerns the influence of social environment and interactions between the prince and people on the character of his leadership during the first period of Serbian independent statehood rather that the style of his later rule.

Knez Miloš Obrenović was one of the leaders of the first Serbian uprising against Turkish rule led by Karadjordje in 1804. After its fall followed by the wave of repressions, Miloš decided to start another uprising in April 1815, this time against the governor of the district of Belgrade but not against the Porta, as the sultan would be ensured by the delegation sent to Istanbul. With Napoleon finally defeated, Prince Miloš could count on the support of victorious Russia. Fearing the spread of the uprising, Turkey made certain concessions. Rather than fighting for power, Prince Miloš tried to take it over from the Ottomans. ${ }^{2}$ Negotiations led to the sultan appointing Maraşli Ali Pasha as governor of the Belgrade district. In November 1815, the newly appointed governor recognized Prince Miloš as supreme knez of Serbia and consented to the establishment of the National Office under Prince Miloš as the supreme administrative and judiciary institution for

\footnotetext{
1 A. Wildavsky, 'A Cultural Theory of Leadership', in: Leadership and Politics: New Perspectives in Political Science, ed. B.D. Jones, University Press of Kansas 1989, p. 100.

2 B. Jelavić, C. Jelavić, The Establishment of the Balkan National States, 1804-1920, Seattle-London 1977, pp. 36-37; М. Екмечић, Стваране Југоставије 1790-1918, 1-2, Београд 1989, 1, pp. 163-164.
} 
Serbian people. ${ }^{3}$ Karadjordje, at this time an exile in Austria, opposed the politics of Prince Miloš. When he returned to Serbia in 1817, Miloš ordered him killed and sent his severed head to the sultan in Istanbul, the move characteristic of the ruthless methods that would become his trademark. In the same year, the Skupština (Parliament) proclaimed Miloš 'supreme hereditary prince and ruler of the people', ${ }^{4}$ which the sultan would only later approve.

After ascending the throne as Prince of Serbia, Miloš ruled like a despot, fully subscribing to the Ottoman culture of power. ${ }^{5}$ He ignored the National Office, prevented its assuming any real power and treated its officers as servants. ${ }^{6}$ Already the 1820s saw several rebellions against Prince Milošs lawless and ruthless rule and fiscal oppression. Vuk Karadjić pointed to numerous evil deeds committed by Prince Miloš: murder, torture, greed, corruption, and exploitation. ${ }^{7}$ In 1824, following the publication of his history of contemporary Serbia, he was warned not to publish again without the ruler's seal of approval. ${ }^{8}$

As the sultan's hatti-sherif transformed Serbia into an autonomous principality, Prince Miloš became its hereditary ruler. Serbian officials were to collect taxes, regulate the functioning of the Orthodox Church and other aspects of communal life. Landed estates of the spahijas were confiscated and the Muslims were prohibited from living in rural areas. ${ }^{9}$ The hatti-sherif also stipulated the establishment of the Assembly and the Council but Prince Miloš rejected it despite the opinion of many Serbian leaders who hoped that the victory would restore the historic knežine (self-government) system that had existed until 1804. This form of political organization of Serbian society had been tolerated by the Ottomans. ${ }^{10}$ Convinced that full independence from the Ottomans could only be achieved through the centralization of power, Prince Miloš retained the office of knez but degraded it to the position of village chief. ${ }^{11}$

Thus, the centuries-long presence of spahijas and čfluk sahibijas (landlords) in Serbian rural life, their collecting taxes and forced labor ended. ${ }^{12}$ For centuries,

${ }^{3}$ Jelavić, Jelavić, Establishment, p. 36.

4 Екмечић, Стваране Југославије, 1, p. 164; Ј. Продановић, Уставни развитак и уствне борбе у Србији, Београд 1936, p. 24.

5 W.S. Vucinich, 'Some Aspects of The Ottoman Legacy', in: The Balkans in Transition. Essays on the Development of Balkan Life and Politics since the Eighteenth Century, ed. C. \& B. Jelavich, Hamden 1974, p. 89.

${ }^{6}$ С. Јовановић, Друга влада Милоша и Михаила, Београд 1933, pp. 461-462.

7 Продановић, Уставни развитак, pp. 36-37. P. Pavlovich, The Serbians: the Story of a People, Toronto 1988, p. 126.

8 Вукова преписка, књига II, Београд 1907, р. 556.

9 Jelavić, Jelavić, Establishment, p. 55.

10 В. Стојанчевић, Милош Обреновић и юегово доба, Београд 1966, pp. 400-401; М. Свирчевић, Локална управа и развој српске државе, Београд 2011, pp. 84-85.

11 Продановић, Уставни развитак, рр. 28-29.

12 V. Karadjić, Danica 1826, 1827, 1828, 1829, 1834, Beograd 1969, p. 158. 
Serbian peasants had lived by the Ottoman principle that the land was formally the property of the sultan but practically of those cultivating it. ${ }^{13}$ Now, the land would formally belong to Prince Miloš who confirmed the Ottoman principle. ${ }^{14}$ The Ottoman-style feudalism ended in 1833 as the peasants became the owners of their land. Rejecting Vuk Karadjić's advice, Prince Miloš was instrumental in this change by preventing the emerging of Serbian landed gentry. ${ }^{15}$ In order to preserve his popularity, he also slightly modified his despotic rule and granted certain economic privileges to peasants. ${ }^{16}$ Serbia became one of only few nations at the time where peasants became landowners. ${ }^{17}$ Milorad Ekmečić ascertains that in fact it is the character of peasants which was 'the principal cause of the country's backwardness' ${ }^{18}$ and consequently the complete liberation of the people would have required the peasants themselves getting rid of 'their inner Turk', that is overcoming their mentality of enslavement, fear, and passivity. According to Trojan Stojanović, the ancient beliefs and practices of Serbian peasants would continue to inform the people's attitudes towards work well into the mid- $20^{\text {th }}$ century. ${ }^{19}$ Paradoxically, acquiring land ownership and social security contributed to the preservation of outdated extensive farming for the century to come. ${ }^{20}$ Passivity, poverty and fear of authority coincided to prevent Serbian society from entering the phase of dynamic change. Quite the contrary, attaining land ownership appeared such a great compensation for the centuries of oppression, the coming of the peasant Arcadia, ${ }^{21}$ that it would stall social change and the emergence of active bourgeoisie. Detrimental to development was also the absence of any road system in Serbia. ${ }^{22}$ Another factor working against social modernization was traditional collectivism based on the conviction that the individual's very survival in a difficult environment where food was scarce depended upon being a member of community. Instead of social mentality change, the disintegrating traditional community of zadruga was replaced by the similar albeit larger peasant principality and rural collectivism was transplanted onto the structures of the state. Thus, the leadership of Prince Miloš was influenced by the mentality of Serbian society, convinced of the virtues of collective communal life, and the peasants' hostility towards change and modernization.

13 S.K. Pavlowitch, Serbia. The History behind the Name, London 2002, p. 34.

${ }^{14}$ Екмечић, Стваране Југославије, 1, p. 222; L. Despotović, Srpska politička moderna. Srbija u procesima političke modernizacije 19. veka, Novi Sad 2008, p. 55.

15 Екмечић, Стваране Југославије, 1, р. 220.

16 Стојанчевић, Милом Обреновић, pp. 410-411.

17 М. Екмечић, Дуго кретаюе између клаға и ораға. Историја Срба у новом веку (1492-1992), Нови Сад 2011, р. 216.

18 Ibid.

19 T. Stojanović, Balkanski svetovi. Prva i poslednja Evropa, Beograd 1997, pp. 291-292.

${ }^{20}$ М. Екмечић, Стварағе Југоставије, 2, р. 59.

${ }^{21}$ М. Перишић, 'Град и грађанин у Србији крајем 19. Века', Историјски записи 71 (1998), nos. 3-4, p. 114.

22 Екмечић, Стваране Југоставије, 2, pр. 237-238. 
Doubtless, Prince Miloš knew his people and understood their needs, even if satisfying them would be detrimental to the state's development. Understandably, acquiring land ownership and expelling the spahijas from villages were the principal objectives of the masses and realizing them over a dozen or so years was the great achievement of Prince Miloš gaining him respect and tolerance of his subjects. His adapting of the Ottoman model of ruler $^{23}$ seemed quite natural to the majority of the people except for a small bureaucratic and intellectual elite deeply scornful of his conduct of a little sultan. ${ }^{24} \mathrm{After}$ the centuries of captivity, the first Serbian ruler proved little different from the Ottomans with regard to methods of government. He also adopted the Ottoman lifestyle ${ }^{25}$ and his greed rivaled the most notorious oriental satraps. Soon, he became the richest man in the Balkans.

Forced to abdicate in 1839, Prince Miloš returned to power in 1858. In his first address to the people, he called them 'his strength' and declared to act with the people and for the people ${ }^{26}$ and to satisfy all their voiced demands. ${ }^{27}$ This having proved impossible, he was able to 'splendidly deceive' the people proving a great demagogue and manipulator ${ }^{28} \mathrm{He}$ liked to talk with common people, he would joke and laugh, praise and admonish; he would scare with outbursts of anger and charm with kindness. He would promise to care while imposing excessive taxation..$^{29}$ He masterfully controlled the people's emotions what earned him the peasants' respect and approval albeit they may have felt disappointed that breaking free of the Ottoman rule had not reduced the tax burden: paradoxically, it became even greater in their own state. ${ }^{30}$

The personality of Prince Miloš certainly enhanced the effectiveness of his demagogy and leadership. As a politician, he was energetic, resolute, intelligent, forward-thinking, capable of grasping the situation quickly and selecting appropriate means to deal with it. He was a prolific orator and used the Skupština as a tribune to communicate with the people. His words resonated with the people, were remembered and circulated. Among the people who were largely illiterate,

${ }^{23}$ By co-ruling with the Turkish governor of Belgrade, Prince Miloš became part of the Ottoman system of power; Продановић, Уставни развитак, р. 23.

24 В. Дворниковић, Карактерологија Југословена, Веоград 1939, р. 861-862.

${ }^{25}$ M. Marinković, The Shaping of the Modern Serbian Nation and of Its State under the Ottoman Rule (in:) Disrupting and Reshaping Early Stage of Nation-Building in the Balkans, ed. M. Dogo, G. Franzinetti, Ravenna 2002, p. 43; Jovanović ascertains that Prince Miloš adapted despotism directly from Turks; Јовановић, Друга влада, p. 467.

${ }^{26}$ Јовановић, Друга влада, р. 130.

27 Ibid., p. 141.

${ }^{28}$ Faced with public outcry against money-lenders and usury, Prince Miloš had debt securities destroyed and ordered the borrowers to pay back principal sums only, with no interest; ibid. pp. 128-129.

29 Стојанчевић, Милош Обреновић, р. 388.

30 Ibid., pp. 180-181. 
oral tradition was instrumental in creating, already during his first reign, and then maintaining his myth as the prince of the people. Remembered as the one who had expelled the Turks from Serbia, he became something of a venerated saint: many wanted to kiss his hand or to touch his clothes. ${ }^{31}$

Jovanović argues that Prince Miloš could have returned to power and assume full control by the will of the people (as a result of the rebellion against the regime of the Constitutionalists) because of the persisting popular belief that he knew and understood the needs of the people better than anyone else. Consequently, he tried to address the people directly and ignore the administration established by his predecessors. ${ }^{32} \mathrm{He}$ was a natural-born populist and his demagogy was very effective with uneducated masses but his rule run counter the self-governing and collectivist spirit of Serbian society. ${ }^{33}$ So, how was he able to hold onto power for 24 years? For the peasant majority, his principal achievement was granting the land to peasants and thus providing them with a measure of social security. His despotism was opposed by the elders and a small intellectual elite but not by the peasants. However, the limitless greed of Prince Miloš stalled the development of the merchant class, for example he had the monopoly on the import of salt and export of pigs, the main product of Serbian economy. ${ }^{34}$

The dynamic and attractive personality of Prince Miloš, his direct manner and demagogical skill helped him cover up his multiple sins: despotism, destroying self-government, cruelty, greed, deception..$^{35} \mathrm{He}$ ruled over the nation of specific social structure: poor peasants constituted $95 \%$ of the population. He regarded them as the core of the nation, By granting them land and thus preserving the system of small farms, he at the same time gave them some minimum of existence and a measure of social and psychological security. Not only was this system traditional and familiar but it also shielded them from economically competing with large farms. The peasants had little idea about alternative forms of government while their ruler provided them with the sense of security and self-worth ('You the people are my strength'). The peasants' low mobility, the absence of a road system, the underdevelopment of towns - all these factors contributed to the fragmentation of social ties and fatalist outlook, the features which - according to Wildavskyi - are conducive to despotic authority. ${ }^{36}$

${ }^{31}$ Јовановић, Друга влада, р. 135; Н. Макуљевић, Уметност и национална идеја у ХІХ веку, Београд 2006, p. 99.

32 Jovanović calls this period of Prince Milošs 'plebiscite monarchy'; Јовановић, Друга влада, p. 132.

33 Ibid., p. 133.

34 Продановић, Уставни развитак, р. 38.

${ }^{35}$ Стојанчевић, Милош Обреновић, р. 407.

${ }^{36}$ Wildavskyi, A Cultural Theory, pp. 107-109. 


\section{Nikola Pašić}

The political leadership of Nikola Pašić should be analyzed in the dual context of the creation of leadership and his personal leadership qualities, the former being of more interest here, particularly his national leadership rather that his party leadership, and the attitudes of Serbian society which influenced the type of leadership since there existed in the Balkans special and specific conditions for this process to enfold.

Nikola Pašić was born in the town of Zaječar, studied in Switzerland (he graduated from the Technical University in Zurich) and devoted his entire life to Serbian politics. He was the founder of the Radical Party, Serbia's first modern political party, and headed it for 50 years. He was an MP (in Serbia and the Kingdom of Serbs, Croats and Slovens) for 38 years and served as a minister or prime minister for 22 years; he was also president of the Skupština and mayor of Belgrade. His lifelong activity exerted an enormous influence upon the establishment of a parliamentary system in Serbia and then Yugoslavia (Kingdom of SCS). ${ }^{37}$ The period after the overturning of the Obrenović dynasty in 1903 marked the peak of Pašić's career as his influence on public life in Serbia (and then Yugoslavia - Kingdom of SCS) became domineering.

Formed under the influence of Svetozar Markovićs socialist ideology, Pašić's attitude underwent radical changes over the years. ${ }^{38}$ Early on, he shared Marković's view that the nation's political rights would be best guaranteed by the socio-political system based on the traditional self-government system of knežine as an antidote to authoritarian despotism..$^{39}$ In time, however, he understood that Serbia was just at the beginning of the process of building a modern nation and relatively quickly switched to conservatism and centralism. ${ }^{40}$ The process of Serbia's transition from agrarian and patriarchal community to civil society had only started. ${ }^{41}$

The first national convention of the Radical Party on 7 August 1882 in Kragujevac, with the majority of delegates 'dressed in traditional peasant costume',

37 Ћ. Станковић, Никола Пашић. Прилози за биографију, Београд 2006, p. 285. Some historians regard the period 1903-1914 as the 'golden age of Serbian parliamentarism,' but others point to its significant deformations; O. Popović-Obradović, Kakva ili kolika država. Ogledi o političkoj i društvenoj istoriji Srbije XIX i XX veka, Beograd 2008, p. 332.

38 A.N. Dragnich, The Development of Parliamentary Government in Serbia, New York 1978, p. 63.

39 Ћ. Станковић, Никола Пашић и југословенско питане, 1-2, Београд 1985, 1, p. 45.

40 This was criticized by the faction of Independent Radicals which opted for a social democratic system and real pluralism; Popović-Obradović, Kakva ili kolika država, pp. 281, 284-285.

${ }^{41}$ Ibid., p. 323. Serbia's social structure in the early $20^{\text {th }}$ c.: peasants constituted $87.31 \%$ of the population, $54.6 \%$ of farms were smaller than 5 hectares; Д. Стојановић, Србија и демократија 1903-1914: историјска студиа о „златом добу српске демократије”, Београд 2003, p. 27. J. Tomasevich (Peasants, Politics and Economic Change in Yugoslavia, Stanford 1955, p. 206) quotes somewhat different numbers: ca. $1897,46 \%$ of farms were no bigger than 5 hectares. 
became an important stage in the development of Pašić's political philosophy. ${ }^{42}$ There, Pašićs formulated the basic creed of his political leadership: he would invoke the principal role of peasants in Serbia's history and contemporary life, refer to their universal values, and rely on their awareness of national and religious unity. He exalted their pride and lifestyle. Reflecting on the history of Serbia over recent decades, he uttered the famous words: 'gunjac and opanak' (shepherd's cape and moccasins), in reference to the characteristic elements of peasant dress, and metaphorically to its wearers. With rhetorical emphasis repeating the phrase several times, he presents the peasants as the core of the nation. 'Gunjac and opanak' have liberated the country from Turkish rule; 'gunjac and opanak' have sprinkled the land with their blood so that 'liberty, truth, and equality [emphasis mine - M.D.] could sprig from it'; 'gunjac and opanak' have built roads, schools, administrative buildings and continue to fell forests and cultivate the fields, working ceaselessly in the heat, rain, and bitter cold to feed the people. 'Gunjac and opanak' guard the borders and defend the country from attack; 'gunjac and opanak' stand for the Serbian people who have created the nation and maintain it with their sweat and toil, who protect lives and property, who contribute their knowledge and experience to the common weal. The peasant has built the nation and therefore he is the nation's sovereign. Pašić maintained that while no party dared take this sovereign right away from the peasants, there was only one actively defending it - his Radical Party. ${ }^{43}$ The party's programmatic manifesto published in Samouprava on 8 January 1881 identified its key objectives on the international and internal scene. The former concerned the uniting of all Serbian territories, which was the common goal of all parties, the latter postulated granting voting rights to all adult males to ensure the whole nation's participation in government in accordance with Pašićs idea of legitimization through winning the majority of peasants' votes. ${ }^{44}$

It is worth emphasizing that Pašićs personality stood in contrast to the character of the people which only makes his leadership talents more apparent. Calm, phlegmatic, almost slow, patient, cunning and goal-oriented, he departed from the stereotype of the Serb as impulsive and belligerent and often lacking persistence. ${ }^{45}$ Also within the Radical Party, his caution helped maintain balance between its patriarchal agrarian and social democratic wings ${ }^{46}$ albeit over the years the criticism

42 Станковић, Никола Пашић и југословенско питане, 1, p. 114. A year later the party already had 60 thousand members.

43 Ћ. Станковић, Сто говора Николе Пашића. Вештина говорништва државника, 1, Београд 2007, pp. 102-103.

44 The Radicals supported self-government on the level of commune but not of district and so they departed from Svetozar Markovićs conception of self-government. М. Вуковић-Бирчанин, Никола Пашић 1845-1926, Müchen 1978, p. 16.

45 J. Цвијић, Балканско Полуострво и јужнословенске земле, Београд 2011, p. 375.

46 Станковић, Никола Пашић. Прилози за биографију, р. 316. 
towards the leader would build up and result in the emergence of the so-called Independent Radicals.

Pašić strove to maintain the Radical Party's dominant position on the Serbian political scene thanks to the unswerving support of peasants and the voters of peasant roots $^{47}$ (there was property qualification and not universal suffrage). Maintaining this support over an extended period of time required cultivating such values dear to the peasant electorate as collectivism, patriarchalism, and egalitarianism, even at the price of stalling modernization as the peasants did not want change. They valued tradition and were satisfied with their land ownership which they considered fundamental for maintaining and continuing their way of life although the majority of farms were autarchic and provided only minimal subsistence. ${ }^{48}$ The triad of Pašić, the Radical Party and peasant masses projected the collective ideal of the state and goals of the poor, agrarian and mostly classless society in the late $19^{\text {th }}$ century. The Radicals rejected the liberal ideology in favor of the conservative and traditionalist program whose fundamental premises were social equality and collectivism. ${ }^{49}$ The Radicals were the only political party communicating with the masses using the language, phrases and comparisons referring to the peasant experience, and consequently their message was not only understandable but also enthusiastically received. ${ }^{50}$

Pašić and the so-called Old Radicals identified with the people and viewed the party and peasant nation as one. Pašić emphasized the organic character of this connection. With the Radical Party representing $85 \%$ of society, he considered its absolute dominance in the Skupština only natural. Pašićs conception of democracy was not based on real pluralism. ${ }^{51}$ This was opposed by Independent Radicals arguing that modern political parties had to refer to clear sociopolitical divisions and promoting the idea of the modern left called 'radical democracy' by Jovan Žujovićs2 but the 'independents' never prevailed for a longer period.

Pašić treated the Skupština dominated by the Radical Party's peasant MPs as an omnipotent organ (absolutization of parliament), its powers transgressing parliamentary democracy. Dubravka Stojanović compares it to the National Convention in France during the French Revolution. Pašić viewed the Skupština as the holder of absolute power realized through the appropriation of the prerogatives of the executive branch of government and giving unlimited legitimization

${ }^{47}$ In 1903-1905, there were some 25-30\% peasant MPs so they did not dominate the Skupština; D. Parusheva, 'Political elites in the Balkans, Nineteenth and Early Twentieth Century: Routes to Career', Études Balkaniques 4 (2000), p. 76.

48 Стојановић, Србија и демократија, p. 28.

49 Popović-Obradović, Kakva ili kolika država, p. 225.

50 Dragnich, The Development of Parliamentary Government, p. 64.

51 А.Л. Шемјакин, Идеологиа Николе Пашић. Формираюе и еволуиија (1868-1891), Београд 2008, p. 289.

52 Ibid. pp. 286-287; А. Столић, Српске политичке генераије (1788-1918), Београд 1998, р. 108. 
to the prime minister's actions..$^{53}$ The opponents of Pašić's regime accused him of creating the system which, like that of Stambolov in Bulgaria, was formally liberal and preserved all institutions of public life but in reality extinguished any liberty. ${ }^{54}$

Pašić was familiar with the political organization of Western societies but used parliamentary democracy to monopolize power in the hands of his Radical Party. He succeeded because his party focused exclusively on protecting the interests of peasants, expressing their views and giving them the sense of self-worth. Pašić was well aware of cultural differences between Western Europe and Serbia (and the Balkans in general): he defended them from a civilizational perspective and thus his argument for the conservative peasant values was forceful and convincing. He attacked Western culture by comparing it to the 'plague ${ }^{35}$ while promoting the mixture of Slavonic culture and Orthodox Christianity which he exalted as 'Slavonic Orthodox civilization. ${ }^{56}$ In 1926, Pašić declared: 'When I talk of freedom, I do not mean nihilist individualism. As the largest unity, the state is above us all and its freedom cannot suffer from individual freedoms. ${ }^{57}$

Following the assassination of King Alexander Obrenović in 1903, Pašić's support of the Karadjordje dynasty opened the period of his greatest political successes. Aware of the country's needs and also of its social structure, he relied on his intuition and experience and strove to use the peasants' support to strengthen his political power. To the peasants, the rhetoric and political instruments he employed were not only understandable but also seemed just. Although there was no universal suffrage in Serbia, the Skupština reflected the country's social structure and, in contrast to many contemporaneous nations, it did not become an exclusive body dominated by bureaucratic and intellectual elites. It represented the largest social group which in reality deformed the system of representation. With the dominance of peasants in the nation's social structure, the political monopoly held by the party representing them was a form of 'parliamentary dictatorship. ${ }^{58}$

It must be remembered that there were events in Pašić's life which could have destroyed his career. The 1883 revolt against King Milan ended with Pašićs defeat and he was forced into exile in Bulgaria. Six years later, he returned but in 1899 was accused of participating in an attempt at the reinstated King Milan's life. Pašić's career and party leadership hung in balance as defending himself he

53 Стојановић, Србија и демократија, р. 51.

54 Д. Стојановић, 'Уље на води: политика и друштво у модерној историји Србије', in: Љ. Димић, Д. Стојановић, М. Јовановић, Србија 1804-2004 - три виђенюа или позив на дијалог, Београд 2005, р. 131.

55 Шемјакин, Идеологиа Николе Пашић, pp. 240-241. "Because all members of an egalitarian regime claim immediate access to higher principles, their filth is the imposition by other of practices members do not accept", Wildavskyi, A Cultural Theory, s. 107.

56 Ibid., pp. 248-249.

57 After: ibid., p. 281.

${ }^{58}$ In the first election after the coup d'état in May 1903, the Radical Party won $75 \%$ of the votes and $88 \%$ (!) of the seats; Popović-Obradović, Kakva ili kolika država, p. 226. 
began to accuse his comrades. ${ }^{59}$ But the years of his greatest influence in Serbian politics were still ahead.

Throughout his ups and downs, Pašić was able to retain the leadership of the masses. The secret of his popularity puzzled his contemporaries. Pera Todorović, the Radical Party's leading intellectual, observed: 'Pašić never knows what he wants or what he does not want. He wants everything and nothing. He never faces the events, he shuffles along. ${ }^{60}$ According to Vladimir Dvorniković, Pašić resembled the typical Serbian peasant in his ability to win people over without ever fully committing himself. His slow speech, apparent clumsiness, convoluted way of expressing his expectations, his oriental passivity and fatalism would have seemed detrimental to leadership but in his case they were the opposite. Serbian peasants believed that Pašić brought them good luck (irrationality). ${ }^{61}$ His long, white beard made him look like a sage (mysticism) ${ }^{62}$ It seems that his political experience and personality intertwined to shape him in the image of the society he sincerely admired and wanted to lead and the image of the people became a mirror in which he saw his own reflection. In this way, an integral connection was manifested between the condition of Serbian society, its character, values, and internal structure, and the type of political leadership represented both by Prince Miloš, elevated to his position by events, and Nikola Pašić, who deliberately went into politics. The sum of their respective victories and defeats seems quite similar but overall they were both immensely successful in the face of extremely challenging circumstances. Perhaps, in the historically and culturally specific Balkan environment, the sum of their ups and downs reflected the essence of national experience. The history of the Serbs in the $19^{\text {th }}$ and $20^{\text {th }}$ centuries illustrates the influence of historical determinants on the nation's development. At the turn of the $19^{\text {th }}$ century, the situation of Serbian people was tragic and after 1830 they could have regarded themselves as the nation of great historical - and historic - success. At the same time, they petrified their way of life while social and economic change proved much smaller than it might have been expected.

Pašić deliberately employed the populist rhetoric whose symbolism resonated with the simple people: they felt appreciated and proud of being the core of the nation and state. By contrast, according to Queen Natalia, King Milan Obrenović neither loved his country nor understood. His personal physician Djoka Jovanović noted that Milan did not believe in the Serbian race and was indifferent towards Serbia and Serbian people. ${ }^{63}$ In this situation, Nikola Pašić, wholeheartedly upholding the values dear to Serbian peasants, became the people's true leader. The prime

59 Дворниковић, Карактерологија Југословена, р. 881.

60 С. Јовановић, Влада Александра Обреновића, 1, Београд 1929, p. 126.

61 Дворниковић, Карактерологија Југословена, pp. 880-882.

62 Cvijić notes that leaders who appear surrounded by mystery appear to exert the most powerful influence on the Serbs; Цвијић, Балканско Полуострво, р. 377.

63 П. Крестић, 'Кнез и краљ Милан у мемоаристици', Историјски часопис 54 (2007), pp. 201-202. 
minister's personal traits set him apart from many other politicians who were dynamic, open, eloquent, etc. Slow, cautious, postponing decisions, taciturn, not a charismatic speaker, soft talking, hiding his real thoughts, he turned these individual and distinctive features to his advantage. His secretiveness seemed mystical and was conducive to irrational expectations that he would always find some solution to apparently hopeless situations: 'Baja knows what to do.' ${ }^{34}$ The word baja ('little brother') expressed respect for age and experience that was only natural in Serbian patriarchal culture. According to Dvorniković, the political type represented by Pašić and his moral structure reflected the overall socio-psychological image of the social environment he identified with and the atavist depth of its revolutionary self-government movement. ${ }^{65}$ Pašićs methods were also criticized. Western intellectuals attributed him with negative traits associated with the Balkans' past, including moral ruthlessness, 'oriental' hajduk mentality, intolerance of real talents, and political cronyism. ${ }^{66}$

Pašićs type of political leadership, informed by his extensive general knowledge and professional expertise (civil engineering), political experience, and skillful demagogy, satisfied the expectations of the masses. Although some were irritated by his taciturn and secretive manner, the majority were impressed by thus communicated 'mystique of power' rising to meet internal and external challenges. Pašić was very careful in his choice of words, answers, and proposed solutions. Intellectually superior to the majority of Serbian society and his party comrades, he managed to effectively communicate his deep concern with the situation of common people and his respect for the collective hero ('gunjac and opanak'). When unable to quickly improve the economic situation of peasants, he tried to present his policies as just and not exclusivist and to convince the peasants that they had owned their liberation from Turkish rule to their own spiritual strength, stoicism, and conservatism and consequently they were now both entitled and obliged to participate in the building of the Serbian state. This was probably the most sophisticated element of Pašićs plan, informed by his acute understanding of the virtues and weaknesses of Serbian society. He wanted to protect these values and integrate them in the building of the nation. ${ }^{67} \mathrm{D}$. Stanković asserts that by employing almost Jacobin methods, Pašić managed to remake the patriarchal Serbian peasant or worker, hitherto suffering the sometimes tyrannical power of bureaucrats and policemen, into the true subject of Serbian politics. ${ }^{68}$

${ }^{64}$ Станковић, Сто говора Николе Пашића, 1, p. 47.

65 Дворниковић, Карактерологија Југословена, p. 881. Dvorniković points to similar personality traits in King Nicholas I of Montenegro.Educated in Paris, he was a man of two cultures, his attitude fusing atavism and modernism; ibid., pp. 888-889.

${ }^{66}$ I. Banac, Nacionalno pitanje u Jugoslaviji, Zagreb 1995, p. 126.

${ }^{67}$ Nikola Pašić's speech at Smeredevo 9/21 March 1889: Станковић, Сто говора Николе Пашића, 1, p. 129.

68 Ibid., p. 8. 
The Radicals tried to solve the problem of Serbia's economic and social underdevelopment by promoting the program of territorial ambitions and nationalism ${ }^{69}$ (the national program's constant feature from Prince Miloš to Slobodan Milošević). In 1907, Pašić declares that his Radical Party has been able to withstand multiple attacks and make many sacrifices because it has believed that free, constitutional and parliamentary Serbia is essential to Serbhood and that 'because of the character of our society, only such Serbia could be the center of Serbhood and assume the role of Piemont. ${ }^{70}$

The phenomenon of Pašić was grounded in social processes enfolding in Serbia. The dissonance between the nation's political modernization and the slowness of social change was greater than anywhere else. The impressive success of Serbian peasants, whose struggle and perseverance had resulted in the emerging of Serbia as a peasant and de facto social state, determined the character of modern Serbia's political life. The people were convinced that they owed this success to their own strength, struggle and simple, traditional values which had helped them survive captivity. Consequently, the nation's political leaders had to accept this line of thought in order to retain political influence. Nikola Pašić is an example of this conception of Serbian politics and the politician's role. From this perspective, the accusations made by his contemporaries concerning his dictatorial methods of holding on to power and even the lack of moral principles are of secondary importance. ${ }^{71}$ What is relevant is how Pašić managed to maintain his political leadership for so many years. He was very apt at reading from the masses' attitudes what was essential to their mindset and therefore should become the foundation of the relation between the people and government. The people did not want their way of life change ${ }^{72}$ and regarded their attachment to land and agrarian tradition as obvious and positive. Like Prince Miloš before him, Pašić had no intention to effect this kind of change. Consequently, the peasants' desire to preserve the extant social model shaped the political leadership of Nikola Pašić as he, with his rational mind and Western education, acknowledged it as the foundation of Serbia's socio-political order in which he also saw a civilizational value.

\section{Slobodan Milošević}

Slobodan Miloševićs personality and his initial social standing were different from those of Nikola Pašić or Prince Miloš but our focus here is on the social

69 Popović-Obradović, Kakva ili kolika država, p. 227.

70 Станковић, Сто говора Николе Пашића, 1, p. 42; M.S. Protić, 'Serbian Radicalism 1881-1903. Political Thought and Practice', Balcanica 38 (2008), p. 179.

71 Дворниковић, Карактерологија Југословена, р. 881.

72 The transformation of the Serbian village had not been completed by 1914; Екмечић, Стваране Југоставије, 2, р. 59. 
environment in which Serbia's president had to act. His formal and real leadership started with his change of attitude towards Kosovo - the key component of Serbian national mythology, although not necessarily regarded as such by the Communists. Miloševićs symbolical and real transformation began at Kosovo Polje, the site of the historic Battle of Kosovo, on the outskirts of Priština, on 24-5 April 1987, although its significance was probably not fully appreciated at the time. Milošević arrived there as a Serbian official to deal with the conflict escalating between the Serbs and Albanians and became an eyewitness to such an incident. When the local Serbs complained to him that they had been beaten by the Albanian police, he uttered the famous words: 'Nobody dares beat you. ${ }^{73}$ Although Yugoslavia still existed and Milošević himself seemed detached from nationalist longings, he thus positioned himself in opposition to Serbia's historic enemy and thus unwillingly assumed the role of national leader. At the time, tension in Yugoslavia had already become so intense that every such gesture was seen as symbolic. By 1988, the so-called anti-bureaucratic revolution was gaining momentum and the power struggle within the political elite intensified. ${ }^{74}$

Milošević's address delivered at Gezimestan on 28 June 1989, on the $600^{\text {th }}$ anniversary of the Battle of Kosovo, became a defining moment of his new role. The speech referred to Serbian national spirit, historical experience and strength gained from living through however traumatic it had been: 'Here, in the heart of Serbia [emphasis mine - M.D.], at Kosovo Polje,' a great battle had been fought. He then ascertains that it is difficult to say whether it was a defeat or victory for Serbian people, whether it made them captives or gave them strength to survive the captivity. ${ }^{75}$ The historical and patriotic rhetoric well expressed the mood of the crowd and popular sentiment.

These two moments in 1987 and 1989 became the milestones in Milošević's career and his transformation from a Communist apparatchik and party functionary of the League of Communists of Yugoslavia ${ }^{76}$ into the Serbian national leader facing historic and personal challenges: the disintegration of the world that had shaped him and forging his new self-identity: 'I am a Serb. ${ }^{77}$ The transformation of leadership in Serbia on the base of equality should be emphasized. According to Wildavsky, equality, as a fundamental value, creates charismatic leaders. He had

${ }^{73}$ N. Popov, Iskušavanja slobode. Srbija na prelazu vekova, Beograd 2010, p. 102.

74 Ibid., p. 105.

75 С. Милошевић, Прилог историји двадесетог века, Београд 2008, р. 24.

${ }^{76}$ He joined the Communist Party while still a student. His ambition was revealed in the declaration he once made to his comrade Radomir Stević Ras: 'When I become [secretary] general, you will be minister of culture'; Ђ. Загорац, Слободан Милочевић. Личне, политичке и судске драме, II изд.: Београд 2006, pp. 11-13.

77 Colović points to the deeply embedded belief that the Serb's character never changes, no matter where the individual lives; I. Čolović, The Politics of Symbol in Serbia. Essays in Political Anthropology, London 2002, p. 64. Many regard Milošević as a Communist but a good Serb; S. Djukić, On, Ona i mi, Beograd 1997, p. 84. 
wanted to become the leader of communist Yugoslavia and became the leader of the Serbs instead and so initially he assumed the role expected of him with some difficulty. He had to face the myth of Kosovo Polje although as a Communist he would rather elaborate the 'mythology' of Kosovo's industrial complex of Trepča, hence the 'ili-ili' ('either-or') dilemma with which Milošević was presented by the majority of public opinion already in 1988: 'He either wants to lead the nation and listen to its voice or he wants to waste time. ${ }^{78} \mathrm{Had}$ not the famous Memorandum SANU in 1986 been a similar postulate addressed to some potential leader? The people had become impatient and expected some decision to be made, preferably opting for the Serbs' national goals. ${ }^{79}$ The people wanted a leader - writes S. Djukić - and they got him. ${ }^{80}$ Boris Jović emphasizes that Milošević was neither nationalist nor chauvinist and that he adopted this stand without ever believing in the ideology ${ }^{81}$ However, as a result of this change of approach, his post-Communist Socialist Party of Serbia (SPS) won four consecutive parliamentary elections in the period of 1990-1998. ${ }^{82}$ During the 1992 campaign, the SPS adopted as its election jingle the famous patriotic song Marš na Drinu. ${ }^{83}$ In Milošević's case, the role of the Serbian people as the key creator of Serbian political leadership seems particularly prominent. The specific nature of Serbian leadership consisted in that it was shaped in the image desired by the people that it followed rather than guided them.

The years of Yugoslavia's disintegration and civil war brought the reiteration of Milošević's choice of the 'national road' but it was opportunistic and informed by his conviction that the process was unstoppable and he could hold on to power only as a Serbian leader. In order to stay in power, he was ready to use the nationalist and populist rhetoric ${ }^{84}$ the Serbs wanted to hear in the hopeless situation following the fall of Yugoslavia. At the Socialist Party of Serbia's convention on 17 February 2000, Milošević argued that 'new fascism' had turned its concentrated forces against small Serbia (in reference to the myth of guerillas fighting the Nazis during World War II) because of her 'habit of being disobedient.' He spoke of the 'shameful' war waged by the world's most developed 19 nations against a small

78 Popov, Iskušavanja slobode, p. 105.

79 Ibid., pp. 104-105.

80 Djukić, On, Ona i mi, p. 83.

${ }^{81}$ B. Jović, Od Gazimestana do Haga. Vreme Slobodna Miloševića, Beograd 2009, p. 31.

82 D. Dolenec, Democratic Institutions and Authoritarian Rule in Southeast Europe, Colchester 2013, p. 175.

${ }^{83}$ M. Thompson, Forging War: the Media in Serbia, Croatia, Bosnia and Herzegovina, Luton 1999, p. 74 .

84 V.J. Bunce and S.L. Wolchik (Defeating Authoritarian Leaders in Postcommunist Countries, Cambridge 2011, p. 92) argue that having realized the imminent fall of the Communist system, Milošević immediately metamorphosed into a Serbian nationalist but his was but a change of rhetoric; seе: Б. Стевановић, Политичка култура и културни идентитети у Србији и на Балкану, Ниш 2008, р. 238. 
country. ${ }^{85}$ His holding on to power during the Kosovo crisis and NATO attack in 1999 was interpreted as an act of characteristically Serbian heroism. While he was likely motivated by his reluctance to step down rather than the desire to defend the nation's pride and interests, the moment finally came when the people hailed him as a national hero. ${ }^{86}$

Miloševićs drive to accumulate power (in 1987-1989 his portraits were displayed at administration offices, as the only one among the members of the collective Presidency of the Socialist Republic of Serbia, despite his being head of the ruling party and not President of the Presidency ${ }^{87}$ ) and also the absence of true nationalist and more 'imperial' longings which would have been expressed in connection with the multinational Yugoslavian state ${ }^{88}$, define his type of leadership as cesarianism - devoid of national concerns but authoritarian and relying on personal power rather than institutions ${ }^{89}{ }^{89}$ disagree with E. Gordy's qualifying Milošević's regime as 'nationalistic authoritarianism" ${ }^{\text {'00 }}$ as his attitude towards the national question was purely tactical. This type of leadership corresponded to the Serbian heritage of passive submissive political culture and the perceived need for a strong leader to restore order ${ }^{91}$ in the situation of chaos, profound economic crisis and sanctions in the late 1990s, especially that there existed the historic tradition of attributing Serbian leaders with savior's powers. ${ }^{92}$ After Milošević's fall on 5 October 2000, such irrational expectations, also regarding the nation's reunification, were transferred onto the person of the newly-elected president Vojislav Koštunica who was implored to 'save us from this madhouse. ${ }^{93}$ In the face of imminent threat, the fate of the nation always seemed more important than individual rights and freedoms which were customarily sacrificed on the altar of collective security and the common weal. ${ }^{94}$ This is also likely connected to the specifically Balkan model of political leadership. Is the hypothesis concerning

${ }^{85}$ Милошевић, Прилог историји, рр. 233-234.

86 Загорац, Слободан Милошевић, р. 12.

87 Jović, Od Gazimestana do Haga, p. 29.

88 Slavoljub Djukić points that to Milošević people were but a 'biological matter' categorized into 'subjects' and 'enemies'; S. Djukić, Kraj Srpske bajke, Beograd 1999, p. 276.

89 S. Antonić, Zarobljena zemlja. Srbija za vlade Slobodana Miloševića, Beograd 2002, p. 432-436. The author reviews different views of Milošević's regime, including the conception of cesarianism and sultanism, according to Max Weber's classification. The former form of regime applies to the period before1997, the flatter to 1997-2000; Popov, Iskušavanja slobode, p. 108; cf. D. Dolenec, Democratic Institutions, p. 168.

90 E.D. Gordy, The Culture of Power in Serbia. Nationalism and the Destruction of Alternatives, Pennsylvania University Press 1999, p. 8.

91 Стевановић, Политичка култура, р. 219; Antonić, Zarobljena zemlja, p. 435. At the same time S. Antonić (ibid., p. 477) points that Milošević lacked the guts of a true tyrant and did not use the army to save his rule.

92 Стевановић, Политичка култура, р. 242.

93 Ibid., p. 238.

94 Ibid., p. 234. 
the existence of such a model justifiable? Jovan Cvijić argues that what he terms 'Balkan civilization' has developed through the process of accumulation of multiple influences: ancient Greek, Byzantine, Slavonic, Oriental, Turkish, and Northern African ${ }^{95}$ and it can accommodate also the type of leadership based on the strong creation of leadership by the people.

First of all, it appears that Milošević's had not been prepared for the leader's role but his change of attitude resulted from the influence of the aforementioned 'mirror' of the people's self-image into which he looked - like Prince Miloš and Nikola Pašić had done before him - and modified his own image accordingly. These three leaders, each one coming from a different background, education and experience, had to modify their leadership in confrontation with the people's self-image. They had to acknowledge that their respective leadership could only be successful if perceived as consistent with the traditionalist and egalitarian self-image of Serbian society and its system of values which cultivated primeval social ties and relations, stability, lifestyle impervious to change, paternalism, living off one's labor, and superiority of tradition over modernity. This model was further propagated after 1945 as a result of the ruralization of towns which was not accompanied by the urbanization of villages. ${ }^{96}$ This process made the character of social relations between the urban and rural population more homogeneous but at the same time slowed down modernization and the society stigmatized by history long remained lethargic. The adoption of Communism further reinforced the sense of collectivism. ${ }^{97}$ Stevanović even refers to re-traditionalism as characteristic of the period. ${ }^{98}$ The duality of Communism manifested itself in the transmission of $19^{\text {th }}$-century traditional values to the seemingly innovative and classless Communist society, surreptitiously preserving the state of collective awareness. ${ }^{99} \mathrm{In}$ its spirituality and mentality, Serbian society appears to have travelled the course of history from Prince Miloš to Milošević little changed. ${ }^{100}$ This made it easier for Milošević to invoke the people's sense of community at the time of danger and use their atavist urge to defend the national hub in order to solidify public support for his leadership. Embedded in the collective Serbian psyche and the nation's historical experience, this reactive mechanism worked this time as well. The people furnished Milošević with attributes of leadership and defined the goal

95 Цвијић, Балканско Полуострво, р. 119.

${ }^{6}$ M. Tripković, G. Tripković, Stranputice Srbije, Novi Sad 2009, pp. 38-39; Gordy, Culture of Power, p. 9; Стевановић, Политичка култура, р. 206.

97 Стевановић, Политичка култура, рр. 222-223.

98 Ibid., p. 208.

99 Tripković, Tripković, Stranputice Srbije, p. 45.

100 Here, Serbian political culture showed a marked tendency. In the 1996 election, 59\% of those who voted for Milošević's SPS and $41 \%$ of the Serbian Radical Party's voters regarded conservatism as a positive value. In the 2001 election this proportion rose to $67 \%$ (SPS) and $58 \%$ (SRP); D.J. Pantić, Z.M. Pavlović, Political culture of Voters in Serbia, Beograd 2009, p. 112, 125. 
he was to realize. As already demonstrated, in Serbia the type of leadership was historically largely determined by the attitudes of the people which is a cultural phenomenon in the European context and a testimony to the impact of historical experience specific to each modern society.

For obvious historical differences, the leadership of Pašić and to some degree also of Prince Miloš was similar in many respects. Antonić identifies a simple analogy between the rule of Prince Miloš and Slobodan Milošević: the citizens' life, freedom, and property were not secure. ${ }^{101}$

What regards Miloševićs personality and behavior as a leader, commentators point to his indifference towards the plight of common people, to the fact that he never walked the streets of Belgrade, never visited the fighting soldiers on the frontline or the wounded at the hospital, never mentioned war widows, invalids, and orphans. ${ }^{102}$ Admonished for his public appearances being too rare, he responded that they had been sufficient. Like Pašić, he preferred to cultivate his image as distanced and mysterious. ${ }^{103} \mathrm{He}$ was pragmatic, loved power and many saw him as a 'cold Narcissus': he did not show emotion, his smile was contemptuous and gaze ironic. ${ }^{104}$ Jović Milošević recalls that despite the many harbingers of upcoming defeat, Slobodan Milošević reacted to the lost election in 2000 with shock and disbelief and he would not vacate the presidential residence for months having settled there so comfortably for a long time. ${ }^{105}$

It is debatable whether Milošević owed his long time in power to a coincidence of historical factors and events or the Serbs really vested in him their hopes in the situation of deep political crisis. Faced with international ostracism, all what was left to the Serbs was to defend the imponderables: their national pride and identity. With the five hundred years of captivity and Turkish rule being the longest period in Serbian history, they were particularly sensitive about their national pride. Seen as the one who had salvaged national dignity, Milošević could count on the people's support and tolerance of his narcissism, thirst for power, arrogance, lack of plan, and even his lack of compassion for human suffering. But accusing him of tyranny seems farfetched as he ruled and stepped down without shedding blood (although the deaths of several politicians have remained mysterious). ${ }^{106} \mathrm{He}$ used refined methods against the opposition ruling in several towns.

101 Antonić, Zarobljena zemlja, p. 467.

102 J.N. Clark, Serbia in the Shadow of Milošević: The Legacy of Conflict in the Balkans, London-New York 2008, p. 48.

103 L.J. Cohen, 'The Milošević Dictatoriship: Institutionalizing Power and Ethno-Populism in Serbia', in: Balkan Strongmen Dictators and Authoritarian Rulers of South Eastern Europe, ed. B.J. Fisher, London 2007, p. 444.

104 Загорац, Слободан Милошевић, pp. 16-17; Clark, Serbia in the Shadow, p. 56; Cohen, Milošević Dictatorship, p. 440.

105 Jović, Od Gazimestana do Haga, pp. 30-31. Jović argues that being SPS' Secretary General, Milošević did not care for the Socialist doctrine.

106 Antonić, Zarobljena zemlja, p. 478. 
He refused the opposition the status of political movement by declaring, in true spirit of Communist propaganda: 'In reality, we do not have a political opposition in Serbia. Instead, we have groups of hired incompetents or profiteers and thieves resorting to blackmail...' He also called the magistrates of the towns controlled by the opposition as 'Jannisaries' and 'Turcituls' (turned-Turks), trying to discredit the opposition in the people's eyes by referring to the painful past and quite paradoxically emphasizing its continuing relevance. ${ }^{107}$ Although the opinions of Milošević as an authoritarian have prevailed, some authors present him as a weak personality, an ex-Communist apparatchik who loved power but was not after its perks ${ }^{108}$ and pomp, did not like extravagant parties and exquisite cuisine. ${ }^{109}$ Miloševićs leadership reflects the influence of populism on contemporary Serbian politics; the influence manifested as a certain style of communicating with society and mobilizing support rather than authoritarianism, the latter being almost impossible to implement against the media and public opinion even in the situation of serious political crisis in Serbia. ${ }^{110}$

\section{Conclusions}

The above analysis of the leadership of the three Serbian politicians active in the $19^{\text {th }}$ and $20^{\text {th }}$ centuries in different circumstances seems justified as the character of Serbian society over the period of some 180 years did not change enough to create political leadership whose characteristics and priorities would have been other than those reflecting the national psyche. Even in the late $20^{\text {th }}$ century, Slobodan Milošević, as President of Serbia (1989-1997) and later Yugoslavia (1997-2000), was able to hold on to power because he respected such constitutive characteristics of Serbian social order as: the spirit of collectivism ${ }^{111}$, patriarchalism (obedience towards a father figure, impossibility to turn against him ${ }^{112}$ ), sense of external and internal threat (fear of treason ${ }^{113}$ ), egalitarianism (free and equal in poverty ${ }^{114}$ ). Despite the passage of time and Serbia's changing situation, the leaders had to respond to the expectations of Serbian people, accentuate the values and symbols appreciated by them, formulate opinions and diagnoses using the familiar idiom,

107 Милошевић, Прилог историји, pp. 236-237.

108 Cohen, Milošević Dictatoriship, p. 441.

109 Загорац, Слободан Милошевић, p. 17.

110 П. Павлићевић, Стил политички лидера у Србији. У периоду 1990-2006 године, Београд 2010, p. 205.

111 Tripković, Tripković, Stranputice Srbije, p. 56; Стевановић, Политичка култура, p. 221.

112 Стевановић, Политичка култура, p. 215.

113 In his public speeches, Milošević strongly emphasized the theme of dissent and betrayal, from Kosovo Polje to present; Милошевић, Прилог историји, pp. 24-25, 181, 236-237, 254.

114 Serbian society is ready to accept democracy but combined with etatism as the principle guiding the running of the nation's есопоту; Стевановић, Политичка култура, s. 220 
exalt the heroism of Serbian people, their autonomous worthiness and spiritual superiority over other peoples and nations. ${ }^{115}$ Presumably, this greatness manifested itself in the readiness of the Serbian 'race of heroes' to make sacrifices and although these heroic choices would regularly result in destruction and suffering, they nevertheless warranted the preservation of the spirit of 'great men.'116

The archetypical Serbian leader was a freedom fighter, something of a hajduk ${ }^{117}$, a hero fighting off external threat, the father and defender of the people (that is the peasants), respectful of their tradition, but also ruthless in dealing with the people's often hostile attitudes towards the state and authority. The Serbs' social history was shaped by small, local communities: the family, zadruga, kneževina. They upheld social equality and were hostile towards external hierarchies and therefore towards authority in general. ${ }^{118}$ This type of organization corresponded to the model of social structure imprinted in the minds of the illiterate peasant traditionally concerned first of all with his own and his family's survival and subsistence. With the goals so atavist and minimalist, the overturning of Turkish rule and acquiring land ownership convinced the people that Serbia thus became the poor rural society's paradise. Every leader had to identify with the values of the peasant nation if he wanted to lead them and the absence of social divisions between the governing and the governed, the only real barrier was the psychological one. ${ }^{119}$ While in other Balkan nations there were many examples of the reception of the Ottoman culture of power, the forming of political leadership in Serbia was profoundly influenced by just the opposite process as in their confrontation with Ottoman Turkey the Serbs had had relied on their readiness to fight, resilience, persistence, traditional social structures, irrationality, and mysticism. Paradoxically, the features that had proven so effective in the struggle with the Ottoman state, would then become a challenge for consecutive Serbian leaders and in time turn into obstacles to Serbia's development. Some Serbian authors have recently conducted the 'vivisection' of the Serb's social attitudes. ${ }^{120}$ These hypercritical analyses sometimes reflect the authors' long-term disenchantment with the nation's continued impossibility to overcome the identified psychological barriers to development: the spirit of collectivism, rejection of individualism, disbelief in the public control of government and administration, passivity, reduced needs. ${ }^{121}$ These barriers made the analyzed political leaders adjust to reality rather than strive to change it as it would be rather difficult, even for a leader of strong personality

\footnotetext{
115 Čolović, Politics of Symbol, pp. 70-71.

116 Ibid., p. 72.

117 B. Despot, Filozofiranje Vladimira Dvornikovića, Zagreb 1975, p. 121.

118 Цвијић, Балканско Полуострво, р. 387.

119 Dragnich, The Development of Parliamentary Government, p. 114.

120 Cf. Стевановић, Политичка култура, passim; Tripković, Tripković, Stranputice Srbije, pp. 40-56; and earlier В. Дворниковић, Карактерологија Југословена, pp. 326-328.

121 Л. Перовић, Зоран Ђинђић и српско друшство, Београд 2013, p. 45.
} 
and oratorical talent, to advocate a political program completely detached from the country's reality. This applied even to Slobodan Milošević whose evolution from apparatchik to pretend Serbian nationalist was the case of political mimicry ${ }^{122}$ as he regarded Serbian nationalism exclusively as an instrument to consolidate his power. This type of leadership was conducive to the 'extreme personalization' of politics in Serbia, a defining characteristic of leadership in the Balkan national states. ${ }^{123}$

The analysis of three distinctive periods in Serbian political history has shown that the long duration processes enfolding in Serbian society were the principal determinant in the formation of the nation's three political leaders discussed in this article: Prince Miloš Obrenović in the early to mid-19 $9^{\text {th }}$ century, Nikola Pašić in the late $19^{\text {th }}$ - early $20^{\text {th }}$ century, and Slobodan Milošević in the late $20^{\text {th }}$ century. However different their personalities, they all looked up to the same 'mirror' of the Serbian people's collective self-image to define the character of their leadership. The Serbian society of the discussed periods and its leaders represented two different velocities. The former was slow to accept change, cultivated the collective memory of experienced wrongs and struggle for survival, was marred by fatalism and passivity, and focused on self-defense based on collectivism. For almost two hundred years, its leaders, whether motivated by personal interest (Prince Miloš), sense of mission (Pašić) or love of power (Milošević), faced the cemented matter resisting modernization. The ruthless Prince Miloš was forced to abdicate by rebellions since resistance against authority was part of Serbian historical heritage. Nikola Pašić, although initially inspired by Svetozar Markovićs political ideology, in the end moved his Radical Party to an extremely conservative position and Slobodan Milošević became - against his deepest conviction - the symbol of Serbian nationalism and collectivism.

Collectivism (reinforced under Communism) was the strength of the Serbian people while patriarchalism was the only accepted form of authority as it corresponded to the desirable model of hierarchical social order, caring government, and egalitarianism which was a key component of collectivism. Although social reality did change, the people's spirit, system of values, psyche and myths remained key determinants of political leadership in Serbia during the entire period from Prince Miloš to Slobodan Milošević despite the discussed leaders' different personality types and motivations.

122 Стевановић, Политичка култура, р. 213.

123 Павлићевић, Стил политички лидера, p. 203; J.S. Roucek, Balkan Politics. International Relations in No Man's Land, Westport (Conn.) 1971, p. 22. 


\section{Model serbskiego przywództwa politycznego: archetyp a współczesność}

\section{Streszczenie}

Artykuł prezentuje analizę charakteru modelu władzy politycznej w Serbii na przestrzeni długiego okresu czasu. Autor prześledził analogie pomiędzy modelami władzy przywódców serbskich w różnych okresach i kontekstach historycznych: księcia Miłosza Obrenowicia (17801860), premiera Nikoli Pašicia (1845-1926) i prezydenta Slobodana Miloševicia (1941-2006). Przez cały ten długi czas model sprawowania przywództwa pozostał niemal niezmieniony w odpowiedzi na określone oczekiwania, odzwierciedlające wartości uznawane przez serbskie społeczeństwo za fundamentalne, w szczególności zaś: stabilność relacji społecznych, egalitaryzm, kolektywizm i konserwatyzm. Ponieważ wartości te niemal nie ulegały zmianie w analizowanym okresie, aktualny pozostał archetyp serbskiego przywódcy jako rzecznika egalitaryzmu, wojownika i trybuna ludowego, jaki zrodził się w reakcji na dominację osmańską.

\section{Сербское политическое руководство: архетипы и современность}

\section{Аннотация}

В статье анализируется степень прочности модели политического руководства в Сербии опираясь на ценности, которыми руководствуется в общественной жизни сербское общество; к ним принадлежат: устойчивость общественных отношений, эгалитаризм, коллективизм, консерватизм. В статье исследуется вопрос существования сходства между, очень отдаленными по времени, моделями руководства кн. Милоша Обреновича (1780-1860), премьер-министра Николы Пашича (1845-1926) и президента Слободана Милошевича (1941-2006), как сербских руководителей. Анализ базируется на убеждении о принципиально похожим типе руководства в настолько длинный период времени, так как такое руководство ожидаемо обществом. Архетип сербского руководителя, эгалитариста, воина и трибуна, был сформирован в ходе борьбы за выживание под османским доминированием. Он продолжает оставаться сильным эталоном политического руководства в Сербии.

\section{Bibliography}

Antonić S., Zarobljena zemlja. Srbija za vlade Slobodana Miloševića, Beograd 2002.

Balkan Strongmen Dictators and Authoritarian Rulers of South Eastern Europe, ed. B.J. Fisher, London 2007.

The Balkans in Transition. Essays on the Development of Balkan Life and Politics since the Eighteenth Century, ed. C \& B. Jelavich, Hamden 1974.

Banac I., Nacionalno pitanje u Jugoslaviji, Zagreb 1995.

Bunce V.J., Wolchik S.L., Defeating Authoritarian Leaders in Postcommunist Countries, Cambridge 2011.

Clark N.J., Serbia in the Shadow of Milošević: The Legacy of Conflict in the Balkans, LondonNew York 2008.

Cohen L.J., 'The Milošević Dictatorship: Institutionalizing Power and Ethno-Populism in Serbia, in: Balkan Strongmen Dictators and Authoritarian Rulers of South Eastern Europe, ed. B.J. Fisher, London 2007.

Цвијић Ј., Балканско Полуострво и јужнословенске земле, Београд 2011. 
Čolović I., The Politics of Symbol in Serbia. Essays in Political Anthropology, London 2002.

Despot B., Filozofiranje Vladimira Dvornikovića, Zagreb 1975.

Despotović L., Srpska politička moderna. Srbija u procesima političke modernizacije 19. veka, Novi Sad 2008.

Djukić S., Kraj Srpske bajke, Beograd 1999.

Djukić S., On, Ona i mi, Beograd 1997.

Dogo M., Franzinetti G. ed., Disrupting and Reshaping Early Stage of Nation-Building in the Balkans, Ravenna 2002.

Dolenec D., Democratic Institutions and Authoritarian Rule in Southeast Europe, Colchester 2013.

Dragnich A.N., The Development of Parliamentary Government in Serbia, New York 1978.

Дворниковић В., Карактерологија Југословена, Веоград 1939.

Екмечић М., Дуго кретаюе између клаға и ораға. Историја Срба у новом веку (1492-1992), Нови Сад 2011.

Екмечић М., Стваране Југоставије 1790-1918, 1-2, Београд 1989.

Gordy E.D., The Culture of Power in Serbia. Nationalism and the Destruction of Alternatives, Pennsylvania University Press 1999.

Jelavić B., Jelavić C., The Establishment of the Balkan National States, 1804-1920, Seattle-London 1977.

Јовановић С., Друга влада Милоша и Михаила, Београд 1933.

Јовановић С., Влада Александра Обреновића, 1, Београд 1929.

Jović B., Od Gazimestana do Haga. Vreme Slobodna Miloševića, Beograd 2009.

Karadjić V., Danica 1826, 1827, 1828, 1829, 1834, Beograd 1969.

Крестић П., 'Кнез и краљ Милан у мемоаристици', Историјски часопис 54 (2007).

Leadership and Politics: New Perspectives in Political Science, ed. B.D. Jones, University Press of Kansas 1989.

Макуљевић Н., Уметност и национална идеја у XIX веку, Београд 2006.

Милошевић С., Прилог историји двадесетог века, Београд 2008.

Pantić D.J., Pavlović Z.M., Political culture of Voters in Serbia, Beograd 2009.

Parusheva D., 'Political elites in the Balkans, Nineteenth and Early Twentieth Century: Routes to Career', Études balkaniques 4 (2000).

Павлићевић П., Стил политички тидера у Србији. У периоду 1990-2006 године, Београд 2010.

Pavlovich P., The Serbians: the Story of a People, Toronto 1988.

Pavlowitch S.K., Serbia. The History behind the Name, London 2002.

Перишић М., 'Град и грађанин у Србији крајем 19. Века', Историјски записи 71 (1998), nos. 3-4.

Перовић Л., Зоран Ђинђић и српско друшство, Београд 2013.

Popov N., Iskušavanja slobode. Srbija na prelazu vekova, Beograd 2010.

Popović-Obradović O., Kakva ili kolika država. Ogledi o političkoj i društvenoj istoriji Srbije XIX i XX veka, Beograd 2008.

Продановић Ј., Уставни развитак и уствне борбе у Србији, Београд 1936.

Protić M.S., 'Serbian Radicalism 1881-1903. Political Thought and Practice', Balcanica XXXVIII, Beograd 2008.

Roucek J.S., Balkan Politics. International Relations in No Man's Land, Westport (Conn.) 1971. Србија 1804-2004 - три виђеньа или позив на дијалог, ред. Љ. Димић, Д. Стојановић, М. Јовановић, Београд 2005.

Свирчевић М., Локална управа и развој српске државе, Београд 2011.

Станковић Ћ., Никола Пашић и југословенско питаюе, Београд 1985.

Станковић Ћ., Никола Пашић. Прилози за биографију, Београд 2006. 
Станковић Ћ., Сто говора Николе Пашића. Вештина говорништва државника, 1-2, Београд 2007.

Стевановић Б., Политичка култура и културни идентитети у Србији и на Балкану, Ниш 2008.

Стојановић Д., Србија и демократија 1903-1914: историјска студиа о „златом добу српске демократије", Београд 2003.

Stojanović T., Balkanski svetovi. Prva i poslednja Evropa, Beograd 1997.

Стојанчевић В., Милош Обреновић и юегово доба, Београд 1966.

Столић А., Српске политичке генерачје (1788-1918), Београд 1998.

Шемјакин А.Л., Идеологиа Николе Пашић. Формирате и еволуција (1868-1891), Београд 2008.

Thompson M., Forging War: the Media in Serbia, Croatia, Bosnia and Herzegovina, Luton 1999.

Tomasevich J., Peasants, Politics and Economic Change in Yugoslavia, Stanford 1955.

Tripković M., Tripković G., Stranputice Srbije, Novi Sad 2009.

Vucinich W.S., 'Some aspects of the Ottoman legacy', in: The Balkans in Transition. Essays on the Development of Balkan Life and Politics since the Eighteenth Century, ed. C. \& B. Jelavich, Hamden 1974.

Wildavskyi A., A Cultural Theory of Leadership, in: Leadership and Politics: New Perspectives in Political Science, ed. Bryan D. Jones, University Press of Kansas 1989.

Вукова преписка, 2, Београд 1907.

Вуковић-Бирчанин М., Никола Пашић 1845-1926, Müchen 1978.

Загорац Ђ., Слободан Милочевић. Личне, политичке и судске драме, II изд.: Београд 2006.

Miroslaw Dymarski, Professor at the Institute of Political Science University of Wroclaw (Poland), historian and political scientist; his research interests include: European studies, contemporary history and history of political thought; especially history of Poland 1939-1945, the Balkans and Central Europe in the $19^{\text {th }}-20^{\text {th }} \mathrm{cc}$; , he is the author of numerous publications on these topics (miroslaw.dymarski@uni.wroc.pl).

Miroslaw Dymarski, prof. dr hab., Instytut Politologii Uniwersytetu Wrocławskiego; historyk i politolog, specjalizujący się w europeistyce, historii najnowszej oraz myśli politycznej; zainteresowania badawcze koncentrują się na historii Polski 1939-1945, Bałkanach i Europie Środkowej w XIX-XX w.; autor wielu publikacji na te tematy (miroslaw.dymarski@uni.wroc.pl). 